\title{
Kualitas Interaksi Sosial antara Penjual dan Pembeli di Taman Pintar Book Store Yogyakarta
}

\author{
Amestia Prasinata Panggabean \\ Program Studi Psikologi Fakultas Ilmu Pendidikan \\ Universitas Negeri Yogyakarta \\ Amestia01@gmail.com atau amestia.prasinata2015@student.uny.ac.id
}

\begin{abstract}
The seller and the buyer's social interaction occurred because of the mutual influence and benefit relationship on both sides. The seller need the buyer to buy their commodity, and the buyer needs the seller to provide commodity and services they needed. The objective of this research is to show the difference in social interaction quality at the morning, afternoon, and evening. This research used quantitative research method to 8 female subjects aged between 21-29 years old. Data collection method are observation and interview. Quotation technique are behaviour tallying and charting for 3 hours as a sample based on 11 indicators and 6 intervals. The type of interview is survey interview. Data analysis method is descriptive quantitative. The result of this research shows 11 indicators used to assess the interaction of the seller with the highest percentage social interaction occurred at the afternoon that is $34,43 \%$, and 4 main factorsaffecting social interaction between the seller and buyer.
\end{abstract}

Keywords: social interaction, buyer, seller

Abstrak. Interaksi sosial antara penjual dan pembeli terjadi karenahubungan timbal balik yang saling mempengaruhi dan menguntungkan. Penjual membutuhkan pembeli untuk membeli barang dagangannya, dan pembeli membutuhkan penjual untuk menyediakan barang dan jasa yang dibutuhkan. Tujuan penelitian ini untuk melihat perbedaan kualitas interaksi sosial pada pagi, siang, dan sore hari. Penelitian menggunakan metode penelitian kuantitatif terhadap 8 subjek dengan usia antara 21 sampai 29 tahun dan berjenis kelamin perempuan. Metode pengumpulan data adalahobservasi dan wawancara. Teknik pencatatan behavior tallying and charting selama 3 jam sebagai sampel berdasarkan 11 indikator dan 6 interval. Jenis wawancara yang dilakukan adalah wawancara survey. Analisis data menggunakan deskriptif kuantitatif. Hasil penelitian menunjukkan ada 11 indikator yang digunakan untuk menilai interaksi yang dilakukan oleh penjual dengan persentase interaksi sosial tertinggi terjadi pada siang hari yaitu 34,43\%, serta 4 faktor utama yang mempengaruhi interaksi sosial antara penjual dan pembeli.

Kata kunci: interaksi sosial, pembeli, penjual

\section{PENDAHULUAN}

Interaksi sosial timbul karena manusia selain sebagai makhluk individual, juga merupakan makhluk sosial. Manusia sebagai makhluk individual mempunyai dorongan atau motif untuk mengadakan hubungan dengan dirinya sendiri, sedangkan manusia sebagai makhluk sosial

mempunyai dorongan untuk mengadakan hubungan dengan orang lain. Dorongan atau motif sosial inilah yang mendorong manusia untuk mencari manusia lainnya untuk mengadakan hubungan atau mengadakan interaksi sosial (Walgito, 2003). Hal ini sesuai dengan ajaran 
Aristoteles (384-322 SM), seorang ahli filsafat Yunani kuno yang menyatakan dalam ajarannya bahwa manusia adalah zoon politicon, yang artinya manusia itu sebagai makhluk sosial yang pada dasarnya selalu ingin 'bergaul' dalam masyarakat (Herimanto\& Winarmo, 2008).

Kecenderungan manusia untuk berhubungan dengan orang lain, mendorong terjadinya komunikasi dua arah yang mengandung aksi dan reaksi (Fatnar \& Anam, 2014). Aksi dapat diartikan suatu tindakan atau perbuatan yang dilakukan seseorang, sedangkan reaksi adalah suatu respon terhadap keberadaan orang lain. Tanpa adanya aksi dan reaksi, maka interaksi sosial tidak terjadi. Interaksi sosial hanya akan dapat berlangsung antara pihak-pihak apabila terjadi reaksi dari kedua belah pihak. Interaksi contohnya ketika dua orang wanita berada di tempat yang sama dan duduk bersebelahan, tidak ada tutur kata, tidak ada jabat tangan atau bentuk perilaku yang melibatkan kontak fisik, tetapi tanpa diketahui salah satu wanita tersebut merasa terganggu dengan aroma parfum wanita di sebelahnya, dan secara perlahanlahan mengubah posisi duduknya, hal ini juga merupakan interaksi sosial karena telah memberikan rangsangan atau stimulus dan mengubah perasaan dari orang yang bersangkutan.

Menurut Herimanto dan Winarno (2008), ada dua sifat interaksi sosial, yaitu interaksi sosial asosiatif dan interaksi sosial disosiatif. Interaksi sosial asosiatif adalah bentuk interaksi sosial yang memiliki sifat positif, seperti kerja sama (cooperation), akomodasi (accomodation), asimilasi (assimilation), akulturasi (aculturation), dan paternalism, sedangkan interaksi sosial disosiatif adalah bentuk interaksi sosial yang bersifat negatif, seperti persaingan (competition), kontravensi, pertikaian, pertentangan atau conflict.

Interaksi yang terjadi antara penjual dan pembeli, baik itu di pasar tradisional maupun pasar modern adalah bentuk transaksi perdagangan. Hal ini menunjukkan bahwa interaksi sosial antara penjual dan pembeli tergolong kepada interaksi sosial asosiatif dengan bentuk kerja sama (cooperation). Cooley (Soekanto, 2012) mengatakan bahwa kerja sama adalah proses apabila orang menyadari bahwa mereka mempunyai kepentingan-kepentingan yang sama dan pada saat yang bersamaan mempunyai cukup pengetahuan dan pengendalian terhadap diri sendiri untuk memenuhi kepentingan tersebut. Hal ini sesuai dengan tujuan penjual dan pembeli melakukan interaksi untuk memenuhi kebutuhankebutuhan atau kepentingan-kepentingan yang sama.

Defenisi interaksi sosial tidak hanya berfokus pada perilaku atau tindakan yang dapat diobservasi atau dapat diamati, tetapi terjadi apabila manusia mengadakan hubungan yang secara langsung berpengaruh terhadap system syarafnya sebagai akibat dari hubungan yang dimaksud (Herimanto \&Winarmo, 2008).

Menurut Herimanto dan Winarno (2008), interaksi sosial memiliki ciri-ciri yaitu pelakunya lebih dari satu orang; Ada komunikasi antarpelaku melalui kontak sosial; Memiliki maksud dan tujuan, terlepas dari sama atau tidaknya tujuan tersebut dengan yang diperkirakan oleh pelaku; Ada dimensi waktu yang akan menentukan sikap aksi yang sedang berlangsung.

Adapun syarat terjadinya interaksi sosial menurut Soekanto (2012) adalah apabila memenuhi 2 syarat, yaitu kontak sosial dan komunikasi sosial. 
Kata "kontak" (Inggris: "contact") berasal dari bahasa Latin yaitu con atau cun yang artinya bersama-sama, dan tango yang artinya menyentuh. Dalam pengertian sosiologi, kontak sosial tidak selalu terjadi melalui interaksi atau hubungan fisik, sebab orang bisa melakukan kontak sosial dengan pihak lain tanpa menyentuh pihak lain yang terlibat. Kontak social juga dapat diartikan sebagai gejala sosial yang saling berhubungan, berhadapan, bertatap muka antara dua individu. Kontak dapat bersifat primer dan sekunder. Kontak primer terjadi ketika ada kontak langsung dengan cara berbicara, jabat tangan, tersenyum, dan sebagainya. Kontak sekunder terjadi dengan perantara, misalnya melalui telepon, radio, TV, dan sebagainya.

Komunikasi sosial adalah proses memberikan tafsiran pada perilaku orang lain yang berwujud pembicaraan, gerakgerik badaniah atau sikap, atau perasaanperasaan apa yang ingin disampaikan orang tersebut. Dengan tafsiran pada orang lain, seseorang memberi reaksi berupa tindakan terhadap maksud orang lain tersebut. Secara singkat diartikan sebagai cara penyampaian pesan dari satu pihak ke pihak yang lain sehingga terjadi pengertian bersama.

Sama halnya dengan interaksi sosial lainnya, interaksi sosial di pasar juga merupakan proses yang sangat penting dan pasti terjadi. interaksi sosial yang seperti ini sering dikatakan interaksi antara penjual dan pembeli. Interaksi sosial antara penjual dan pembeli dilataberlakangi oleh kebutuhan yang sejalan. Penjual membutuhkan pembeli untuk membeli barang dagangannya, dan pembeli membutuhkan penjual untuk membeli barang atau jasa. Hubungan ini lah yang disebut hubungan timbal balik atau saling mempengaruhi antara penjual dan pembeli.

Penjual adalah orang yang melakukan sebuah akifitas pemasaran yang ditujukan untuk menyampaikan barang kepada konsumen yang berasal dari produsen. Upaya ini dilakukan tentu untuk menghubungkan sekaligus memberikan keuntungan antara konsumen dan produsen Konsumen akan bisa memenuhi kebutuhanya dan produsen bisa memperoleh laba dari hasil penjualannya. Beberapa kegiatan yang dilakukan oleh penjual adalah mencari pembeli, mempengaruhi pembeli, serta memberi arahan agar pembeli bisa menyesuaikan kebutuhannya dengan produk yang ditawarkan dengan ikatan perjanjian harga dan menguntungkan kedua belah pihak.

Bentuk-bentuk penjualan oleh penjual ini bisa dikelompokkan menjadi penjualan tunai cash), penjualan kredit dan penjualan tender, penjualan ekspor dan penjualan titipan. Secara keseluruhan dari penjualan ini dipengaruhi oleh kondisi atau daya beli pasar. Ini disebabkan oleh faktor barang yang tersedia, harga yang ditawarkan, dan syarat penjualan. Dari segi penjualan juga tak terlepas dari modal si penjual. Modal tersebut berupa kemampuan untuk lebih mengenalkan produk pada konsumen dengan berbagai cara.

Parise, Guinan, dan Kafka (2016) menunjukkan bahwa penjual harus mampu menjelaskan produk yang ditawarkannya dengan baik dan interaktif, untuk dapat membuat konsumenmerasa tidak terpaksa, "nyambung" dengan yang ditawarkan penjual dan merasa sesuaidengan yang dibutuhkan secara kognitif dan emosional. Tentu saja hal ini akan terjadi apabila ada interaksi yang baik antara penjual maupun pembeli. Interaksi sosial yang baik sangat berperan penting dalam pengambilan keputusan pembeli untuk membeli suatu barang. Claudiu-catalin \& Dorian-Laurentiu (2014) menunjukkan bahwa terdapat dua faktor yang memengaruhi konsumen dalam membeli produk yaitu faktor intrinsik yang berasal dari diri sendiri dan juga faktor ekstrinsik yang berasal dari luar diri 
sendiri/lingkungan seperti rekomendasi dari teman.

Kata Pembeli berasal dari Bahasa Inggris, yaitu consumer, yang menurut $\mathrm{KBBI}$ diartikan sebagai seseorang atau sesuatu perusahaan yang membeli barang tertentu atau menggunakan jasa tertentu, atau seseorang yang mengunakan suatu persediaan atau sejumlah barang. Ada juga yang mengartikan setiap orang yang menggunakan barang ataujasa".Pembeli adalah orang yang melakukan sebuah bentuk usaha untuk memenuhi kebutuhan dan mendapatkan barang/jasa. Nilai manfaat barang tersebut akan dinikmati oleh pembeli itu sendiri. Bentuk bentuk pembelian berdasarkan pembayarannya juga hampir sama dengan penjualan. Karena dua proses ini terjadi dalam suatu waktu dan satu kesepakatan, maka pembelian ini bisa saja dilakukan secara tunai ataupun pembayaran kemudian.

Menurut Sandstrom dan Dunn (2014), interaksi sosial juga dapat membangun kepercayaan antara kedua pihak, termasuk penjual dan pembeli. Kepercayaan akan terbentuk melalui interaksi antara satu pihak dengan pihak yang lainnya secara terus menerus. Kepercayaan menurut Rousseau et al. (dalam wahyudi, Milla, dan Muluk, 2017), adalah wilayah psikologis yang merupakan perhatian untuk menerima apa adanya berdasarkan harapan terhadap perilaku yang baik dari orang lain. Kepercayaan ini lah yang nantinya dapat mempengaruhi loyalitas konsumen atau pembeli terhadap penjual. Morgan dan Hunt (dalam Aryani dan Rosinta, 2010) mengatakan bahwa tingginya kepercayaan akan dapat berpengaruh terhadap menurunnya kemungkinan untuk melakukan perpindahan terhadap penjual lainnya, atau sering disebut dengan loyalitas. Kepercayaan dapat mempengaruhi loyalitas (Bastian, 2014). Menurut Reichheld dan Sasser (dalam Aryani dan Rosinta, 2010), Loyalitas pelanggan merupakan suatu bentuk perilaku konsumen yang mengarah pada kemungkinan pembelian ulang, meningkatnya loyalitas pada harga, dan memberikan rekomendasi pada pihak lain (Foster dan Cadogan, dalam Bastian, 2014).

Sandstrom and Dunn (2014) mengatakan bahwa Interaksi sosial juga memungkinkan terjadinya perubahan dalam suatu ikatan antar dua pihak. Ikatan yang awalnya lemah dapat berubah menjadi ikatan yang kuat melalui interaksi sosial yang terus menerus terjadi dalam kurun waktu yang lama. Interaksi sosial di pasar juga memungkinkan terjadinya perubahan ikatan antara penjual dan pembeli. Ikatan yang awalnya hubungan 'bisnis' antara penjual dan pembeli, dapat berubah menjadi hubungan yang lebih intim, seperti pertemanan atau munculnya rasa kekeluargaan, tergantung kepada waktu yang dibutuhkan dan juga kualitas interaksi sosial yang terjadi antar dua pihak.

Bagaimana jika ternyata data yang dilapangan justru berbeda dengan teorinya? Bagaimana jika suatu interaksi sosial itu justru tidak dapat mengubah suatu hubungan bisnis menjadi hubungan yang lebih kuat? Apakah hal ini bisa saja terjadi? Jawabannya semua mungkin saja terjadi.

Belakangan ini, pertumbuhan penggunaan internet di Indonesia meningkat pesat dari 78 juta di tahun 2014 menjadi 132,7 juta di tahun 2016 selain kegiatan browsing, chating, membuka $e$ mail, membaca berita, download konten, dan bermain game, sebagian besar netizen menggunakan internet untuk mengakses social media yaitu sebesar $97,4 \%$ dan $63,5 \%$ nya pernah melakukan transaksi online. Pesatnya penggunaan internet untuk mengakses internet dan transaksi jual beli online berdampak pada perubahan cara perdagangan yang tadinya dilakukan 
secara tradisional dengan tatap muka dan pembayaran tunai, berkembang menjadi penjualan melalui website atau disebut juga e-commerce dengan berbagai macam bentuk pembayaran seperti transfer ATM, internet banking, paypal, rekening bersama, dan beberapa metode pembayaran lainnya. Artinya interaksi sosial yang terjadi antara penjual yang sebelumnya terjadi secara tradisional, yaitu melibatkan 2 syarat terjadinya interaksi sosial, kini hanya melibatkan 1 syarat saja, yakni komunikasi sosial. Dan itu terus saja berlanjut hingga menjadi suatu fenomena yang sering disebut fenomena belanja online.

Hal ini lah yang mendorong dilakukannya penelitian ini, adalah untuk menilai kualitas interaksi sosial yang terjadi antara penjual dan pembeli di Taman Pintar Book Store Yogyakarta. Suatu pusat perbelanjaan buku di Yogyakarta yang masih terlepas dari bisnis transaksi jual beli online. Penelitian ini bertujuan untuk menilai kualitas interaksi sosial antara penjual dan pembeli terlepas dari adanya pengaruh e-commerce atau bisnis online. akan tetapi, meskipun terlepas dari bisnis online, interaksi sosial di Taman Pintar Book Store Yogyakarta tidak dapat berjalan begitu saja. Ada beberapa faktor lain yang dapat mempengaruhi proses interaksi sosial, seperti waktu atau cuaca panas yang membuat penjual tidak ingin berinteraksi dengan pembeli dan sebagainya. Lalu bagaimana interaksi sosial yang terjadi antara penjual dan pembeli?

Dapatkah penjual dan pembeli melakukan interaksi sosial terlepas dari beberapa kendala yang dapat menghambat interaksi sosial? Atau justru sebaliknya kualitas interaksi sosial yang terjadi antara penjual dan pembeli justru menurun akibat dari kendala-kendala tersebut? Lalu adakah perbedaan interaksi sosial yang terjadi pada pagi hari, siang hari dan sore hari? Atau interaksi sosial yang terjadi justru stagnan atau tidak mengalami perubahan?

Penelitian ini telah menjawab pertanyaan-pertanyaan tersebut melalui observasi dan wawancara survey yang dilakukan di Taman Pintar Book Store atau yang lebih dikenal dengan nama Shopping Center, yang berlokasi di kompleks Taman Pintar, Yogyakarta. Salah satunya adalah menjawab pertanyaan apakah ada perubahan interaksi sosial antara penjual dan pembeli di pagi hari, di siang hari, dan di sore hari atau justru mengalami stagnan atau menetap. Hasil penelitian ini juga akan menunjukkan beberapa indikator interaksi sosial yang terjadi dalam ruang lingkup pasar atau antara penjual dan pembeli. Indikator tersebut diharapkan mampu menjadi sumber referensi bagi ilmu sosial untuk peneliti-peneliti selanjutnya, sebab saat ini belum ada penelitian yang menjelaskan secara khusus mengenai interaksi sosial dinilai berdasarkan indikator-indikator interaksi sosial.

\section{METODE PENELITIAN}

Penelitian ini bersifat mix method, karena memadukan pendekatan kualitatif dan kuantitatif dalam hal metodologi (seperti dalam tahap pengumpulan data), memadukan dua pendekatan dalam semua tahapan proses penelitian ini. Penelitian ini berfokus pada pengumpulan data yang terukur, menggunakan angka-angka, serta melakukan kuantifikai atas perilaku yang terlihat. Metode pengumpulan data yang digunakan melalui wawancara dan observasi. Lokasi Penelitian dilakukan di Taman Pintar Book Store atau yang lebih dikenal dengan nama Shopping Center, yang berlokasi di kompleks Taman Pintar, Yogyakarta.

Jenis Wawancara yang dilakukan adalah wawancara survey. Wawancara surveydilakukan kepada 8 subjek untuk 
diminta memberikan penilaian terhadap 20 indikator yang telah dibuat atau memberikan tambahan apabila ada indikator lain yang perlu ditambahkan. Ke 20 indikator dikembangkan berdasarkan 2 syarat terjadinya interaksi sosial menurut Soekanto (2012), yaitu kontak sosial dan komunikasi sosial. Penilaian dari 8 penjual menggunakan kategori penilaian dengan skor 1 = tidak penting, skor 2 = rata-rata; skor 3 = penting; skor 4 =sangat penting). Indikator yang skor rata-ratanya dibawah 3 dieliminasi.

Delapan subjek juga diminta untuk menuliskan pendapatnya tentang faktorfaktor yang dapat mempengaruhi interaksi sosial antara mereka dan penjual. Faktorfaktor tersebut nantinya akan digunakan dalam menganalisis penyebab apabila terjadi perubahan persentase pada tiap-tiap data (data pagi, data siang, dan data sore), baik itu meningkat ataupun menurun.

Observasi dilakukan dengan menggunakan 2 jenis observasi yang berbeda, yaitu nonparticipant observation dan participant observation. Nonparticipant observation adalah jenis observasi yang tidak melibatkan observer atau observer tidak mengambil bagian dalam aktivitas yang dilakukan oleh observee, sedangkan participant observation adalah observasi yang melibatkan observer dalam aktivitas yang dilakukan oleh observe (Kusdiyati \& Fahmi, 2015). Observasi dilakukan dengan menggunakan 2 jenis observasi yang berbeda, karena data yang ingin diperoleh berbeda.

Observasi pertama menggunakan jenis nonparticipant observation terhadap 1 subjek dengan teknik pencatatan menggunakan behavior tallying and charting yang dilakukan selama 3 jam sebagai sampel (pagi 1 jam, siang 1 jam, sore 1 jam). Objek amatan yang menjadi fokus utama peneliti pada hari pertama adalah interaksi antara subjek dengan pembeli yang datang ke tokonya selama 1 jam di pagi hari, lalu 1 jam di siang hari, dan terakhir 1 jam di sore hari. Peneliti menggunakan indikator-indikator yang telah dibuat dan dianalisis berdasarkan pendapat para penjual di Taman Pintar Book Store sebagai indikator penilaian interaksi sosial yang terjadi.

Pada observasi pertama, observasi hanya berfokus pada pencatatan frekuensi interaksi yang dilakukan subjek dengan 1 pembeli yang datang ketokonya, artinya apabila ada 2 pembeli yang datang ke toko subjek, maka peneliti hanya akan mengobservasi 1 orang pembeli saja, sedangkan 1 orangnya lagi akan diabaikan. $\mathrm{Hal}$ ini dikarenakan peneliti ingin melihat setiap perkembangan interaksi yang terjadi antara subjek dengan pembeli berdasarkan setiap interval, yaitu 1 menit pertama, 2 menit berikutnya, 3 menit berikutnya, 4 menit berikutnya, 5 menit berikutnya, dan 6 menit berikutnya sehingga total ada 21 menit dengan 6 interval.

Observasi kedua adalah jenis observasi participant observation atau melibatkan subjek. Observasi kedua dikombinasikan dengan wawancara survey. Wawancara survey yang dilakukan oleh peneliti adalah dengan menanyakan pendapat subjek mengenai faktor-faktor yang dapat mempengaruhi interaksi sosial mereka dengan pembeli, yang kemudian dianalisi dengan data yang diperoleh dari 8 subjek pertama. Hal ini ditujukan untuk melihat faktor-faktor apa saja yang dapat mempengaruhi interaksi sosial antara penjual dan pembeli.

Subjek yang diteliti adalah 8 penjual yang diwawancarai dan 1 penjual yang diobservasi di Taman Pintar Book Store. Usia subjek antara 21 sampai 29 tahun dan 
semua berjenis kelamin perempuan. Delapan subjek yang diwawancarai dan diminta penilaiannya mengenai ke 20 indikator interaksi sosial yang telah dibuat sebelumnya, dan menuliskan beberapa faktor-faktor yang menurut subjek dapat mempengaruhi proses interaksi sosial antara penjual dan pembeli. Sedangkan untuk 1 subjek diobservasi berdasarkan indikator, interval, dan waktu (pagi, siang, sore).

Teknik pengambilan sample adalah Nonprobability Sampling untuk 8 subjek. Teknik Nonprobability Sampling adalah teknik pengambilan sampel yang didasarkan pada kondisi/karakteristik tertentu yang khusus (necessary condition) yang telah ditetapkan oleh peneliti (Dantes, 2012). Jenis Nonprobability Sampling yang digunakan adalah purposive sampling, yaitu teknik penarikan sampel didasarkan pada ciri atau karakteristik (tujuan) yang telah ditetapkan peneliti sebelumnya (Dantes, 2012).

Keabsahan data dengan cek dan ricek antar metode analisis data menggunakan deskriptif kuantitatif, karena berusaha menggambarkan atau mendeskripsikan suatu fenomen atau peristiwa secara sistematis sesuai dengan apa adanya. Sedangkan untuk analisis indikator adalah menggunakan $\mathrm{V}$ aiken Berdasarkan data yang diperoleh melalui wawancara survey dengan 8 subjek, terdapat 11 indikator yang memiliki nilai rata-rata 3 ke atas dengan indeks minimal $v$ aiken $>0,3$. Ke-11 indikator tersebut terbagi berdasarkan 2 syarat utama terjadinya interaksi sosial menurut Soekanto (2012), yaitu kontak sosial dan komunikasi sosial.

Kontak sosial terdapat 5 indikator yaitu kontak mata, mendekat, tersenyum, mengangguk, dan menggekeng, sedangkan komunikasi sosial terdapat 6 indikator yaitumenyapa, bertanya, berbincang, tertawa, negosiasi, dan transaksi.

\section{HASIL DAN PEMBAHASAN}

Berdasarkan data yang diperoleh melalui wawancara survey dengan 8 subjek, terdapat 11 indikator memiliki nilai rata-rata 3 ke atas dengan yang indeks minimal v aiken $>0,3$. Ke-11 indikator tersebut terbagi berdasarkan 2 syarat utama terjadinya interaksi sosial menurut Soekanto (2012), yaitu kontak sosial dan komunikasi sosial. Kontak sosial terdapat 5 indikator yaitu kontak mata, mendekat, tersenyum, mengangguk, dan menggekeng, sedangkan komunikasi sosial terdapat 6 indikator yaitu menyapa, bertanya, berbincang, tertawa, negosiasi, dan transaksi.

Table 1.

Subject's Background

\begin{tabular}{llllllllll}
\hline & S1 & S2 & S3 & S4 & S5 & S5 & S7 & S8 & S9 \\
& & & & & & & & & \\
\hline Initials & AN & CS & HS & OF & LO & CS & AS & KF & MA \\
Age (years old) & 24 & 21 & 29 & 22 & 26 & 27 & 22 & 25 & 24 \\
Sex & F & F & F & F & F & F & F & F & F \\
\hline
\end{tabular}


Table 2.

Indikator Interaksi Sosial

\begin{tabular}{|c|c|c|c|}
\hline syarat & Indikator & V Aiken & Mean \\
\hline \multirow[t]{5}{*}{ Kontak Sosial } & Kontak Mata & 0.96 & 3.88 \\
\hline & Mendekat & 0.83 & 3.50 \\
\hline & Tersenyum & 0.83 & 3.50 \\
\hline & Mengangguk & 0.88 & 3.63 \\
\hline & Menggeleng & 0.83 & 3.50 \\
\hline \multirow{6}{*}{ Komunikasi Sosial } & Menyapa & 0.92 & 3.75 \\
\hline & Bertanya & 0.92 & 3.75 \\
\hline & Berbincang & 0.79 & 3.38 \\
\hline & Tertawa & 0.75 & 3.25 \\
\hline & Negosiasi & 0.79 & 3.38 \\
\hline & Transaksi & 1 & 4 \\
\hline \multicolumn{2}{|l|}{ Indeks Min V Aiken } & \multicolumn{2}{|l|}{0.72} \\
\hline \multicolumn{2}{|c|}{$\begin{array}{l}\text { Tabel } 2 \text { menjelaskan bahwa indikator } \\
\text { dengan V Aiken tertinggi adalah 1,00 yaitu } \\
\text { pada indikator transaksi dan indikator } \\
\text { dengan V Aiken terendah adalah 0,75 yaitu } \\
\text { indikator tertawa, demikian juga } \\
\text { berdasarkan rata-rata setiap indikator yang } \\
\text { diperoleh menunjukkan transaksi memiliki } \\
\text { rata-rata (mean) tertinggi dan tertawa } \\
\text { dengan rata-rata (mean) terendah. }\end{array}$} & \multicolumn{2}{|c|}{$\begin{array}{l}\text { menyapa merupakan indikator tertinggi } \\
\text { kedua dan ketiga berdasarkan } \mathrm{V} \text { Aiken dan } \\
\text { rata-rata (mean). Fokus utama observasi } \\
\text { pada hari pertama adalah mencatat } \\
\text { frekusensi interaksi sosial yang dilakukan } \\
\text { subjek tiap interval per } 1 \text { pembeli pada } 1 \\
\text { jam di pagi hari, } 1 \text { jam di siang hari, } 1 \text { jam di } \\
\text { sore hari. Hasil observasi yang diperoleh } \\
\text { dibagi menjadi } 3 \text { data, yaitu data pagi, data } \\
\text { siang, dan data sore. }\end{array}$} \\
\hline
\end{tabular}

Sedangkan kontak mata, bertanya, dan

Table 3.

Persentase (\%) Indikator Interaksi Sosial Pagi Hari

\begin{tabular}{lllllll}
\hline Indikator & Interval 1 & Interval 2 & Interval 3 & Interval 4 & Interval 5 & Interval 6 \\
\hline Kontak mata & 18.18 & 25.00 & 24.00 & 14.29 & 18.75 & 18.18 \\
Mendekat & 13.64 & 22.22 & 16.00 & 10.71 & 6.25 & 9.09 \\
Tersenyum & 9.09 & 11.11 & 8.00 & 7.14 & 6.25 & 9.09 \\
Menyapa & 11.36 & & & & & \\
Bertanya & 22.73 & 16,67 & 20.00 & 10.71 & 12.50 & 9.09 \\
Berbincang & 2.27 & 8.33 & 12.00 & 14.29 & 6.25 & 9.09 \\
Tertawa & & & & 7.14 & 6.25 & 9.09 \\
Mengangguk & 18.18 & 11.11 & 16.00 & 10.71 & 12.50 & 9.09 \\
Menggeleng & 4.55 & 2.78 & 4.00 & 10.71 & 12.50 & 9.09 \\
Negosiasi & & & & 10.71 & 12.50 & 9.09
\end{tabular}




\begin{tabular}{lllllll} 
Transaksi & & 2.78 & & 3.57 & 6.25 & 9.09 \\
Min & 2.27 & 2.78 & 4.00 & 3.57 & 6.25 & 9.09 \\
Max & 22.73 & 25.00 & 24.00 & 14.29 & 18.75 & 18.18 \\
\hline
\end{tabular}

Tabel 3 menunjukkan bahwa pada pagi hari, indikator yang paling banyak dilakukan oleh subjek kepada pembeli pada tiap interval berdasarkan persentase tiap interval adalah kontak mata. Indikator yang paling sedikit dilakukan adalah berbincang pada interval 1, transaksi pada interval 2, menggeleng pada interval 3 , transaksi pada interval 4, transaksi pada interval 5, dan selain kontak mata dan menyapa, semua indikator di interval 6 memiliki persentase yang sama-sama rendah, yaitu 9,09.

Table 4.

Persentase (\%) Indikator Interaksi Sosial Siang Hari

\begin{tabular}{lllllll}
\hline Indikator & Interval 1 & Interval 2 & Interval 3 & Interval 4 & Interval 5 & Interval 6 \\
\hline Kontak mata & 20.27 & 34.62 & 27.59 & 25.00 & 34.04 & 17.95 \\
Mendekat & 4.05 & 11.54 & 8.62 & 7.69 & 2.13 & 5.13 \\
Tersenyum & 5.41 & 9.62 & 5.17 & 3.85 & 2.13 & \\
Menyapa & 20.27 & & & & & \\
Bertanya & 20.27 & 17.31 & 22.41 & 9.62 & 12.77 & 7.69 \\
Berbincang & & & 8.62 & 15.38 & 6.38 & 10.26 \\
Tertawa & & & & 1.92 & 2.13 & 7.69 \\
Mengangguk & 20.27 & 15.38 & 20.69 & 7.69 & 14.89 & 5.13 \\
Menggeleng & 9.46 & 7.69 & 3.45 & 13.46 & 19.15 & \\
Negosiasi & & & 1.72 & 11.54 & 6.38 & 25.64 \\
Transaksi & & 3.85 & 1.72 & 3.85 & & 20.51 \\
Min & 4.05 & 3.85 & 172 & 1.92 & 2.13 & 5.13 \\
Max & 20.27 & 34.62 & 27.59 & 25.00 & 34.04 & 25.64 \\
\hline
\end{tabular}

Tabel 4 menunjukkan bahwa indikator yang paling banyak terjadi pada siang hari di setiap interval adalah kontak mata. Indikator yang paling sedikit dilakukan adalah mendekat pada interval 1, transaksi pada interval 2, transaksi dan negosiasi pada interval 3 , tertawa pada interval 4 dan 5 , dan mengangguk pada interval 6 .

Tablel 5.

Persentase (\%) Indikator Interaksi Sosial Sore Hari

\begin{tabular}{lllllll}
\hline Indikator & Interval 1 & Interval 2 & Interval 3 & Interval 4 & Interval 5 & Interval 6 \\
\hline Kontak mata & 18.03 & 22.22 & 28.57 & 13.89 & 19.05 & 33.33 \\
Mendekat & 11.48 & 13.89 & 4.76 & 11.11 & 9.52 &
\end{tabular}




\begin{tabular}{lllllll} 
Tersenyum & 19.67 & 11.11 & 14.29 & 13.89 & 9.52 & 16.67 \\
Menyapa & 13.11 & 2.78 & & & & \\
Bertanya & 18.03 & 22.22 & 9.52 & 5.56 & 4.76 & \\
Berbincang & & 2.78 & 14.29 & 8.33 & & \\
Tertawa & & & 4.76 & 19.44 & 4.76 & \\
Mengangguk & 11.48 & 16.67 & 9.52 & 8.33 & & 16.67 \\
Menggeleng & 8.20 & 8.33 & 4.76 & 2.78 & 19.05 & \\
Negosiasi & & & 4.76 & 5.56 & 19.05 & 16.67 \\
Transaksi & & & 4.76 & 11.11 & 14.29 & 16.67 \\
Min & 8.20 & 2.78 & 4.76 & 2.78 & 4.76 & 16.67 \\
Max & 19.67 & 22.22 & 28.57 & 19.44 & 19.05 & 33.33 \\
\hline
\end{tabular}

Tabel 5 menunjukkan bahwa indikator yang paling banyak terjadi pada sore hari pada interval 2, interval 3 dan interval 6 adalah kontak mata, sedangkan pada interval 1 tersenyum, interval 4 tertawa, dan interval 5 kontak mata, menggeleng, dan mengangguk. Indikator yang paling sedikit dilakukan adalah menggeleng pada interval 1, menyapa pada interval 2, mendekat, tertawa, menggeleng, negosiasi, dan transaksi pada interval 3, menggeleng pada interval 4, bertanya dan tertawa pada interval 5, dan tersenyum, mengangguk, negosiasi, dan transaksi pada interval 6 .
Hasil penelitian menunjukkan bahwa ada perbedaan antara interaksi sosial di pagi hari, siang hari, dan sore hari, dengan persentase tertinggi ada pada siang hari. Pada pagi hari, persentase interaksi sosial yang terjadi adalah $31,61 \%$, pada siang hari sebesar $34,43 \%$, dan sore hari sebesar $33,95 \%$. Hal ini menunjukkan bahwa terjadi peningkatan interaksi sosial sebesar $2,82 \%$ dari pagi hari ke siang hari, dan akan kembali mengalami penurunan pada sore hari sebesar $0.47 \%$ meskipun masih lebih besar $2,34 \%$ dibandingkan padaa pagi hari.

\section{Persentase Rata-Rata Interaksi Sosial antara Penjual dan} Pembeli

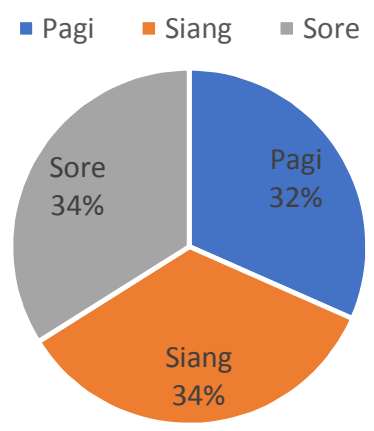

Gambar 1.

Persentase (\%) Rata-Rata Interaksi Sosial antara Penjual dan Pembeli 


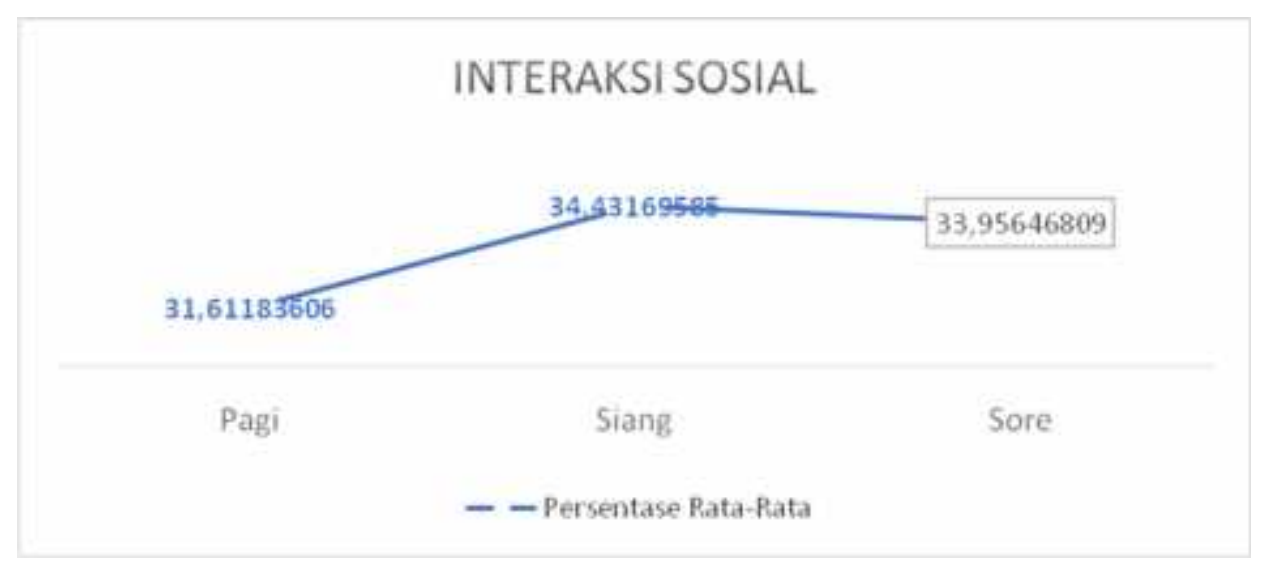

Gambar 2.

Perubahan Interaksi Sosial Pagi Hari, Siang Hari, dan Malam Hari

Perubahan ini, bisa saja dipengaruhi oleh beberapa faktor-faktor dalam interaksi sosial. Berdasarkan hasil hasil wawancara survey yang dilakukan kepada 8 subjek dan hasil observasi pada hari kedua terhadap subjek yang diobservasi sebelumnya di hari pertama, ditemukan bahwa:

1. Faktor Jumlah pengunjung (ramai sepinya pengunjung) faktor pertama yang mempengaruhi interaksi sosial, itulah mengapa persentase pada pagi

2. hari lebih rendah dibandingkan pada siang dan sore hari, karena pada pagi hari jumlah pengunjung yang datang di Taman Pintar Book Store lebih sedikit dari pada di siang dan sore hari.

3. Faktor cuaca, seperti hujan atau panas dapat mempengaruhi mood atau perasaan para penjual dan menghadapi pembeli, atau sebaliknya sikap pembeli terhadap para penjual. Mood atau perasaan ini berdasarkan hasil wawancara menunjukkan dapat mempengaruhi interaksi sosial mereka. Hal ini dapat menjadi alasan mengapa interaksi sosial di siang hari lebih tinggi, tetapi justru beberapa indikator seperti mendekat, tersenyum, berbincang dan tertawa justru menurun pada siang hari, karena indikator-indikator ini sangat dipengaruhi oleh mood atau perasaan penjual.

4. Faktor pembeli, biasanya pembeli yang merupakan orang dewasa lebih dilayani dibandingkan pembeli yang merupakan anak-anak, hal ini menunjukkan adanya seleksi yang dilakukan oleh penjual terhadap pembeli yang datang ke tokonya.

5. Faktor kelelahan juga dapat mempengaruhi keinginan penjual untuk berinteraksi dengan pembeli. Hal ini dibuktikan melalui data observasi yang menunjukkan bahwa persentase interaksi sosial mengalami penurunan di sore hari, tetapi tetap lebih tinggi dibandingkan pagi hari karena jumlah pengunjung di sore hari tetap lebih banyak dibandingkan pagi hari. 


\section{SIMPULAN}

Berdasarkan hasil penelitian yang dilakukan terhadap 8 subjek melalui wawancara survey dan dengan analisis $\mathrm{V}$ Aiken, ditemukan 11 indikator yang dapat digunakan untuk menilai interaksi sosial antara penjual dan pembeli. Ke-11 indikator tersebut adalah: Kontak mata, bertanya, mendekat, mengangguk, tersenyum, berbincang, menggeleng, negosiasi, menyapa, tertawa dan terakhir adalah melakukan transaksi. Ke-11 indikator interaksi sosial yang ditemukan dalam penelitian ini dapat digunakan sebagai landasan teori untuk penelitian selanjutnya.
Hasil lain dari penelitian ini juga menunjukkan ada perbedaan interaksi sosial antara penjual dan pembeli di pagi, siang, dan sore hari, dengan persentase tertinggi terjadi pada siang hari. Adanya perbedaan persentase interaksi sosial antara penjual dan pembeli, baik itu peningkatan atau penurunan, dapat dipengaruhi 4 faktor utama, yaitu jumlah pengunjung (ramai atau sepi), faktor cuaca (panas atau hujan), faktor pembeli (usia, jenis kelamin, sifat), faktor kelelahan. Hal ini diperoleh berdasarkan hasil wawancara. Ke-4 faktor utama ini dapat dijadikan sebagai variabel ekstraneous yang harus diperhatikan untuk penelitian selanjutnya.

\section{DAFTAR PUSTAKA}

Aryani, D., \& Rosinta, F. (2010). Pengaruh kualitas layanan terhadap kepuasan pelanggan dalam membentuk loyalitas pelanggan bisnis \& birokrasi. Jurnal IImu Administrasi dan Organisasi. 7(2). 114-126.

Bastian, D, A. (2014). Analisa pengaruh citra merek (brand image) dan kepercayaan merek (brand trust) terhadap loyalitas merek (brand loyalty) ades pt. ades alfindo putra setia. Jurnal Manajemen Pemasaran Petra. 2(1). 1-9.

Claudiu-Catalin, M., \& Dorian-Laurentiu, F. (2014). Radical brand extensions and consumer profile - a new perspective on innovation and consumer innovativeness. Procedia -Social and Behavioral Sciences. 109. 108-112.

Dantes, N. (2012). Metode Penelitian. Yogyakarta. Andi Offset.

Fatnar, N, V., \& Anam, C. (2014). Kemampuan interaksi sosial antara remaja yang tinggal di pondok pesantren dengan yang tinggal bersama keluarga. Jurnal Fakultas Psikologi. 2(2). 71-75.

Herimanto., \& Winarmo. (2008). Ilmu sosial \& budaya dasar. Jakarta: Bumi Aksara.

Kusdiyati, S., Fahmi, I. (2015). Observasi Psikologi. Bandung: Remaja Rosdakarya.

Myers, D, G. (2012). Social psychology. New York: Mc Graw Hill Education

Parise, S., Guinan, P. J., \& Kafka, R. (2016). Solving the crisis of immediacy: How digital technology can transform the customer experience. Business Horizons (2016). Retrieved March 4, 2016, from http://dx.doi.org/10.1016/

Sandstrom, G, M., \& Dunn, E, W. (2014). Social interactions and well-being: The Surprising Power of Weak Ties. Personality and Social Psychology Bulletin. Retrieved November 29, 2014http://psp.sagepub.com/

Soekanto, S. (2012). Sosiologi suatu pengantar. Jakarta: Rajawali Grafindo Persada. 
Wahyudi, J., Milla, M, N., \& Muluk, H. (2017). Persepsi Keadilan Sosial dan Kepercayaan Interpersonal sebagai Prediktor Kepercayaan Politik pada Mahasiswa di Indonesia. Jurnal Psikologi Sosial 15(1). 59-71.

Waluya, B. (2007). Sosiologi: Menyelami fenomena sosial di masyarakat. Bandung: PT Setia Purna Inves. 